Revista do CESP, Belo Horizonte, v.36, n.56, p. 21-29, 2016

\title{
Teoremas $^{1}$
}

\section{Theorems}

Vilma Arêas

Universidade Estadual de Campinas, Campinas, São Paulo / Brasil

vilmasa@uol.com.br

Resumo: Análise de dois livros publicados em 1979, A Casa de Vidro (Ivan Ângelo) e Operação Silêncio (Márcio Souza). Embora usando procedimentos estéticos diferentes, ambos têm a mesma intenção: compreender a História do Brasil e denunciar seus abusos, para que nada seja esquecido.

Palavras-chave: ficção; História.

Abstract: Analysis of two books published in 1979, The glassy House and Silence in operation. Their authors, Ivan Ângelo and Márcio Souza, although using different literary procedures, intend to comment the Brazilian History in order to point out its abuses not to be forgotten.

Keywords: fiction, History.

Recebido em 5 de junho de 2016

Aprovado em 30 de junho de 2016

${ }^{1}$ Teorema: do grego theórema, "o que se pode observar, espetáculo, objeto de estudo ou de meditação, preceito moral, contemplação". 
Querida Lélia, este texto foi escrito em 1980, um ano após a públicação dos dois livros que aqui comento. Não o publiquei, não sei por que. Mas talvez estivesse esperando uma boa ocasião, que por fim chegou trinta e sete anos depois e o dedico a você, com a admiração e amizade constante.

Em um conto intitulado "Os desastres de Sofia" (LISPECTOR, 1964, p. 9-29), Clarice Lispector traça dois mapas para a busca de um tesouro: o primeiro afirma que só o trabalho árduo garante a obtenção da fortuna. O segundo aponta um jogo cheio de invenção para surpreender o tesouro, que imediatamente se metaforiza, surgindo onde menos se espera, até mesmo "em sujos quintais".

Entretanto esses dois caminhos podem ser compreendidos como um só, variantes que são de uma mesma figuração apoiada nas relações do texto literário com os modelos e as circunstâncias que o fizeram nascer. Se um se mostra confiante no acesso supostamente espontâneo ao que se entende por real, não abre mão do jogo inventivo criado pelo "trabalho árduo", que por sua vez não dispensa a força transformadora da metáfora. O texto literário se coloca deste modo como um lugar específico de redistribuição da ordem da língua, nunca um espaço reconfortante em que as complexas relações que regem a sociedade e a literatura sejam espontaneamente resolvidas. Como não poderia deixar de ser, ambas as variações apresentam suas dificuldades próprias. Arrisquei colocá-las lado a lado, sem reduzir uma à outra.

Os breves comentários que se seguem sobre $A$ Casa de Vidro, de Ivan Ângelo (1979), e Operação Silêncio, de Márcio Souza (1979), elegem um objeto de estudo, têm um mesmo projeto, isto é, rever a história do Brasil para contemplá-la, entender e também denunciar suas distorções, que infelizmente se repetem neste século XXI. Ambos tentaram caminhos formais diferentes, mas não recuaram diante das dificuldades dos teoremas que armaram.

O que de saída impressiona no livro de Ivan Ângelo é seu caráter de objeto bem feito e acabado, uma caixa de vidro cujo fecho parece se oferecer, mas que negaceia uma entrada grátis ou passagem sem dor. Apresentado como um livro de novelas, percebemos no entanto que ele se estrutura como um romance policial sofisticado, em que o protocolar último capítulo é o mapeamento dos quatro anteriores e moldura em que as novelas se encaixam para o estabelecimento do sentido. 
Dizendo de outra maneira, os quatro primeiros capítulos ("novelas") são glosa, comentário e interpretação do último, colocado como mote, sob forma entretanto de estribilho às avessas. Essa reviravolta, ou volta insistente ao ponto de partida, imobiliza o tempo, tornando-o circular, sem saída.

Mas sobre o que versa esse último capítulo?

Vejamos: existem nele três narradores, os dois primeiros ficcionais, apesar das vestes históricas que usam, e o terceiro, sem deixar de ser ficcional, é a máscara do narrador do livro, que grafaremos Narrador para evitar dúvidas. Os três são encaixados um no outro, envolvidos com três mistérios a respeito de um tesouro escondido. $\mathrm{O}$ primeiro mistério, dado como "invenção de um certo Martinho Dias em 1699", em plena crise do sistema colonial português no Brasil, foi resolvido cento e vinte e oito anos depois por Estevam de Saa Perdigão, em 1827, no início do reconhecimento da independência brasileira (1822), que entretanto legitimou a evasão de recursos do Brasil e conciliou elementos liberais com o continuismo da situação colonial; o segundo mistério, "criação requintada" do acima citado Perdigão, foi resolvido em 1968 pelo Narrador de A Casa de Vidro.

Não nos esqueçamos que 1968 foi o ano do AI-5, isto é, do Ato Institucional no governo do Marechal Costa e Silva (1967-1969) ou seja, do arrocho da ditadura militar instalada entre nós em 1964, cuja prática rotineira era a tortura e o assassinato.

$\mathrm{Na}$ pista da resolução do mistério, este Narrador nos confessa haver recebido do anterior "o ouro e a missão"; escreve então o livro que lemos agora. Desta vez o ouro é metafórico, "hum ensinamento" que se dá a entender a bom entendedor. A epígrafe do último capítulo, intitulado "Achado", reafirma a interpretação. Foi retirada pelo Narrador do texto de Perdigão, por sua vez intitulado "Memória do Achamento de hum Ouro qu'estava perdido". A epígrafe reza o seguinte: "q'a acolha como hum ensinamento e taõbem, se a isto se prestar, como hum final divertimento offerecido a pessoa q'se houve em taõ trabalhozas especullaçoens."

Claro está, não se fala aqui em ouro escondido, embora o Narrador tenha explicitamente prometido no início do capítulo que "quem desfizer o terceiro mistério ganha um prêmio: ouro" (p. 215). Investigando melhor, percebemos que o terceiro mistério quem o resolveu foi o próprio Narrador, que infelizmente nada fala sobre a transferência desse prêmio 
ao leitor, que terá de se contentar com o "final divertimento" de "histórias simples demais", no entanto e ao mesmo tempo "uma história difícil".

Este simples resumo já revela o emaranhado e entrelaçamento de histórias e narradores no suceder de períodos críticos da história do Brasil. Para a graça da literatura, os ardís tencionam mais esconder que revelar o tesouro. Este paradoxo nos fornece uma das chaves para a compreensão do que lemos, pois as novelas e o capítulo final oferecem uma visão panorâmica da história do Brasil, com uma clara tentativa de entender nosso tempo a partir de seus fundamentos arcaicos. Por isso, $A$ Casa de Vidro se pretende uma arqueologia dos vários estratos formadores de nosso rosto, uma vez lavado da maquillage dos discursos falsos e/ou ufanistas que o encobrem.

As três primeiras novelas narram com extrema violência a história da dominação colonial portuguesa e inglesa que se desenvolve entre nós desde a Carta de Caminha, fecho de "Conquista", primeira novela. Aqui a promessa de riqueza na pena de Pero Vaz se realiza concreta e torpemente séculos depois nas aventuras do "devasso inglês sir Henry Spencer Ashbee", narradas a seu cunhado, sir Harold. As libertinagens sexuais, teóricas e práticas, colocando para funcionar "seu famoso quatro por dezoito", se ajustam perfeitamente à exploração de operários durante a resolução de uma greve na fábrica em Osasco. Conclui o inglês que bastaria pagar $15 \%$ de aumento salarial se podiam pagar $30 \%$ e tudo se arranjaria. A estratégia seria tratar bem "a gente morena da terra de Vera Cruz", oferecendo cigarros democráticos ao final: "Cigarro aí ô companheiro?" (p. 46).

Assim Pero Vaz de Caminha se deixa ver metido na pele de sir Henry, que defende com unhas e dentes o lucro da empresa, enquanto belisca o biquinho do peito da secretária: "tratando-se bem a essa gente dará essa atitude bons fruitos, e tudo se conseguirá” (p. 48). Estupros, brigas de quadrilha, corrupção policial, desaparição de presuntos, isto é, de assassinados, encontram sua alegoria na noveleta homônima do livro, "A Casa de Vidro":

Para remedio se fazia demonstraçaõ de toda severidade contra quaesqueres revoltas delles, desde açoutes ao pee do Pelourinho â mais severa de enforcamentos e esquartejamentos em praça publica, para terror e exemplo, conforme declaravaõ as sentenças delles, q'se liaõ. (p. 169) 
A prisão era indestrutível apesar de cristalina. Seus reflexos agudos atiram sobre nossos ombros a responsabilidade do crime social, que é sua verdadeira matéria. Pois a história da opressão, diz-nos o texto, se desenrola sob nossos olhos, é perfeitamente transparente, enquanto nós, com passividade, ignorância ou má-fé ajudamos a construí-la. Em consequência, não só fomos capturados para dentro dela, como estamos implicados em papéis contraditórios e absurdos, criados por nossa própria alienação: "Você sabe, ó aqui, está vendo?, daqui eu me vejo lá dentro. Às vezes parece que eu estou sendo interrogado, outras vezes eu é que estou dando porrada" (p. 207).

Da astuciosa acusação não escapa o procedimento poético com suas leis próprias, pois "a perfeição da forma /também/esconde os truques" (p. 188). Em "Achado" a mesma equivalência é retomada.

"Martírio", "Miráculo" e "Mistério" são as palavras-chaves da decifração do mapa do tesouro. Se acolhermos tudo isso como "hum bom ensinamento", isto é, se investigarmos os documentos, se dermos ouvidos aos testemunhos e aos martírios ("martírio" etimologicamente significa "apresentar seu testemunho"), receberemos o ouro, isto é, desvendaremos o sentido do "milagre brasileiro" tão propalado nos anos ditatoriais.

Em vez disso, os depoimentos são elaborados desde o início do período colonial, cravados na carne dos rebeldes a começar pelos "açoutes ao pee do Pelourinho" (p.169), que é naturalmente o lugar de "negro insubordinado". Finalmente, "a ordem é fuzilar os cabeças"(p. 225). A história continua, apresentada pelas epígrafes cuja ordenação também é cruzada, baralhando a ordem com que surgem no texto do último capítulo, de onde são retiradas. A arqueologia é também a das palavras. Os corpos são vistos por dentro, decifrando esqueletos espelhados que deixam ver o buraco das balas. Palavras se metem umas dentro das outras obedecendo às aparências e falseando a etimologia (não é verdade que "rito" simula estar contido em "grito"?) Entender o sentido intrincado e contraditório do conjunto da história do Brasil parece ser mesmo o prometido tesouro.

O próprio Ivan Ângelo reforça seu projeto na explicação ao final das páginas: "são cinco novelas em que o Brasil atual e o antigo se penetram, se iluminam. Tenho necessidade de saber por que o meu país é assim/.../ A minha ficção é uma espécie de investigação".

Diante do preciosismo de construção de A Casa de Vidro, Operação Silêncio pode parecer um livro escrito de um jato, ao sabor da paixão e do nojo, irrefreável como a "poalha de vômito" que atinge quem 
vive ou se debruça sobre a história da América Latina, percorrendo-a do século XVI até hoje, esmiuçando as lendas, os fatos ou o último decreto oficial.

Esse "vômito", que encharca o livro, imitando a violência e o terror do golpe militar, surge principalmente na amargura de Paulo Conti, o narrador, mas também existe como dado concreto, quando prisioneiros políticos, inclusive Conti, são obrigados a limpar as salas, cobertas de fezes, vômito e urina, após a tortura de companheiros (p. 177). O vértice dessa pirâmide é o ano do AI-5, 1968, com suas terríveis consequências, leitmotif da obra.

Para começar, dúvidas: trata-se de um romance ou de um depoimento? Talvez ensaio? Investigação do lugar sempre ambíguo do intelectual? Talvez seja tudo isso, conforme observação de Fernando Peixoto na orelha do livro:

Na verdade Operação Silêncio é um romance que, à medida que se constrói se transforma, sem perder sua narrativa de ficção (constituída de pedaços do real e de cenas quase da farsa picaresca, num ensaio sobre arte (sobretudo cinema e também literatura) e política. Em muitos momentos a sensação é quase o inverso: um vigoroso ensaio sobre arte e política que se dissolve em romance.

O livro é dividido em duas metades, a primeira "O Sobrevivente Paulo Conti", com sua sarcástica e desalentada epígrafe ("Acredito que a obra-prima da língua portuguesa é o texto do AI-5"); a segunda metade, intitulada "O rio de sangue", são 98 páginas que jorram sem pausas, com uma epígrafe de Tertuliano, importante teólogo cartaginês, do século segundo da era cristã: "Acredito nessas coisas porque elas são inacreditáveis".

Mas a forma do livro é a de uma caixa de ressonâncias a partir de materiais diversos, que radicalizam o sentido das palavras escritas. Na primeira parte, os fragmentos que a compõem vêm introduzidos com palavras do Livro Vermelho de Mao Tsé-Tung a sublinhar a distância entre a militância estudantil inspirada pelas palavras de Mao e a prática da resistência em contexto em tudo diverso, distante. Na segunda parte, o método foi o de misturar os tempos onde se movimentam os personagens e as situações, em sequências sucessivas. O filme sonhado por Paulo 
Conti e narrado por ele a um personagem não ultrapassa o estágio da imaginação, pois não consegue chegar às telas, embora una as duas partes, encerrando o livro:

Paulo: a música segue assim, em ritmo flamengo. Voz cantando em off: sueña el rey que es rey y vive/ con este engaño mandando.../Yo sueño que estoy aqui destas prisiones cargado... Pensa: companheiros, a esperança não poderia reviver se ninguém sentisse necessidade dela. A canção vai decrescendo. Plano do mar, os créditos do filme aparecem sobre as vagas do Atlântico até surgir, em silêncio, a palavra FIM.

Talvez possamos considerar esse trecho final como resumo de Operação Silêncio, pois as primeiras páginas, ao se abrirem com referências ao filme imaginado por Conti, se unem às últimas palavras, acima citadas. O doloroso e violento "ritmo flamengo" é perfeito como música ao filme sonhado, tão triste e trágico quanto Operação Silêncio onde ele está, enquanto a voz em off canta o famoso monólogo de Segismundo em La vida es Sueño, de Calderón de la Barca. Trata-se do solilóquio mais famoso do teatro espanhol e ocorre no final do primeiro Ato, quando Segismundo, encarcerado, pensa na vida e em seu destino.

O trecho se ajusta ao ponto-chave do livro, as tristes memórias de Paulo Conti encarcerado nelas mesmas, na lembrança dos mortos, mas que não o impedem de fazer um balanço radical sobre o tipo de relação que os intelectuais mantêm com a sociedade desigual, que papel deverá ter a literatura ou o cinema na luta de classes, de que modo entender a independência relativa da obra de arte: "Griffith, que era um sulista revanchista, racista, ele soube construir as bases da linguagem cinematográfica" (p. 75).

Por qualquer lado que se revolvam essas questões - e Márcio Souza faz análises exigentes do cinema e da literatura brasileira até a década de 1970 -, elas tentam entender a especificidade do problema de nosso país, incluído no quadro mais amplo da América Latina. (O filme de Paulo Conti, por exemplo, é sobre Manco Capac, imperador dos Incas, que em 1536 tentou libertar seu povo, tendo sido violentamente reprimido pelas hostes de Francisco Pizarro. Este também em busca de outro tesouro, o Eldorado, "cidade toda de ouro brilhando contra o lago de águas verdes", p. 165). 
O debate exige parcialidade, afirma Conti, o que gera outra tensão importante no livro -ao mesmo tempo engajamento prático e compreensão teórica, o ponto de articulação entre política e fabulação artística. A clave escolhida é a do desfoque, o fio que passa entre olhar e ver, entre ser e discurso, entre a leitura de Mao Tsé-Tung e a prática política inspirada nele, entre a defasagem do intelectual brasileiro e a produção do exterior que o inspira etc.

Algumas respostas ousadas são encontradas: no Brasil, intelectual é aquele que se esquece. Se a arte idealmente se pretende um texto eficaz (ao contrário do que significa numa cultura associada a ornamento, quando as obras favorecem mais a quem as faz do que a quem as lê ou alcança), neste caso, tanto na língua quanto na política portuguesa/brasileira, manipuladas pelos legistas (letrados), o texto poético fundamental não é nem o de Gil Vicente, proibido e censurado por duzentos anos, nem o de Guimarães Rosa. Ele é, sim, o texto do AI-5, ou, acrescento, o da grotesca comédia, para dizer o mínimo, que se desenrolou ao vivo a 17 de abril de 2016, há 37 anos da publicação dos dois livros.

Impossível esgotar aqui todos os caminhos abertos por Operação Silêncio, ou examinar a bela e "irrazoável" esperança que o encerra ("o vômito vai se dissipar, nós estamos dissipando o medo", p. 207), mas convém estabelecer o ponto de ligação que o uniria a $A$ Casa de Vidro, no tema geral de repensar a história, no intuito de buscá-la nos documentos, raízes, para que ninguém seja inocentado, nenhuma data esquecida. Mais alegórico em Ivan Ângelo (mas o texto instala e desequilibra a alegoria), mais documental em Márcio Souza, sem prejuízo da ficção.

De qualquer modo, o ponto fundamental de $A$ Casa de Vidro e de Operação Silêncio é a descoberta também de outro tesouro, que inverte o ditado "a palavra é de prata, o silêncio é de ouro", ${ }^{2}$ pois o necessário é quebrar esse silêncio, escrever, demitir o intelectual que se esquece, passando a palavra ao intelectual que compreende a tragédia de nossa história. Ambos os livros colocam problemas, superam o círculo fechado de certo romance de denúncia e - tantos anos passados! - permanecem novos e oportunamente atuais. Não propõem soluções. Aliás as soluções podem ser encontradas com argumentos lógicos, mas os problemas só

\footnotetext{
${ }^{2}$ Augusto Abelaira escreveu a peça A Palavra é de Oiro em 1961, durante a ditadura salazarista em Portugal, quando o teatro era escrito para ser lido apenas. A partir do título, o refrão é também invertido. (Cf. ARÊAS, 2008, p. 57-71).
} 
se colocam por meio da imaginação, estimulada pela experiência das dificuldades.

\section{Referências}

LISPECTOR, Clarice. Os desastres de Sofia. In: . A Legião Estrangeira. Rio de Janeiro: Editora do Autor, 1964. p. 9-29.

SOUZA, Marcio. Operação silêncio. Rio de Janeiro: Civilização Brasileira, 1979. ÂNGELO, Ivan. A casa de vidro. São Paulo: Livraria Cultura Editora, 1979.

ARÊAS, Vilma. A comédia segundo Augusto Abelaira. PEREIRA, Paulo Alexandre (Coord.). Augusto Abelaira. Aveiro: Universidade de Aveiro, 2008. p. 57-71. 